New Pentagon rules on overseas students Secrecy threat to sensitive research plans

\title{
Washington
}

Restrictions on the use of foreign research students on non-classified research projects sponsored by the Department of Defense are in the offing. This prospect stems from the requirement, recently emphasized by Congress, that the multi-million dollar research programme sponsored by the department in very high speed integrated circuits should be strictly controlled to prevent the export of technical data of potential military value.

Pentagon officials say they are "bending over backwards" to minimize interference with the freedom of university research in applying controls. These controls were introduced in 1972 as the International Traffic in Arms Regulations (ITAR) to cover the export of unclassified technical data. Many academics, however, see a danger of renewed threats to academic freedom previously raised by secret military research on university campuses.

Because of the uncertainties which abound, the Defense Department has issued guidelines to both universities and private contractors carrying out sponsored research on integrated circuits. Where research can be classified as "process development" and is likely to lead to a specific improvement of military technology, controls will apply and it will be necessary to obtain an export licence from the State Department before the research is even discussed with a foreign citizen. But where the research can be classified as the "general pursuit of knowledge", with no particular application in mind, then controls will not apply.

Pentagon officials admit that there is a "grey area" dividing the two, particularly in materials science research and other areas closely linked to improving the efficiency of semiconductor systems. The Defense Department has told universities of its "preference" that foreign students should not be employed on integrated circuit programmes, but that the programme office will "make a decision based on the nature of the research" where restraint is not feasible.

The consequences could be significant. The proportion of foreign research students in US universities has risen dramatically in the past few years to about 50 per cent - and is particularly high in fields such as computer science, where first degree graduates can command large salaries in the private sector.

Several universities are concerned that strict interpretation of the regulations could reduce flexibility in research

programmes, especially since the Department of Defense is the major supporter of this line of research. There is also mounting anxiety that the regulations might be abused. They are written so broadly that it is a federal crime to discuss with a foreign scientist any research result which might improve the "state of the art", of US military technology without prior approval by the State Department.

These fears have been reinforced by the National Security Agency's attempts to restrict the dissemination of cryptography research results obtained by Dr George Davida of the Georgia Institute of Technology (see Nature 19 February, p.621). Integrated circuit research is less sensitive, but government officials could theoretically use the regulations to close down semiconductor research in universities, on the grounds that, almost by definition, such research must advance the state of the art.

Commercial contractors for the Defense

\section{British gene company opens books}

Britain's national biotechnology company, Celltech, has begun marketing its first product: the monoclonal antibody to leukocyte interferon which, fixed to beads in a fractionation column, can purify interferon 5,000-fold in a single step. But since the discovery (see Nature $\mathbf{2 8 5}$, $446-458 ; 1980$ ) fell before November 1980 , when Celltech negotiated rights to Medical Research Council biotechnical inventions, the National Research Development Corporation will retain a slice of the action. Profits on sales will be divided between Celltech, the corporation and the council.

The researchers who created the cell line, Dr David Secher of the MRC Laboratory of Molecular Biology, Cambridge, and Professor Derek Burke of the University of Warwick, also stand to gain but by different routes. In Burke's case, the standard revenue-sharing agreement will give the University of Warwick half the development corporation's profit; and Burke and colleagues in his laboratory will receive half of that, less the university's costs in running the laboratory for the relevant period. Secher, on the other hand, must look to his employer, the Medical Research Council. The council's agreement with Celltech allows for some reward for the researcher, but it is not clear at this stage how much. There is a standard arrangement for "inventors" in which a joint council-corporation panel meets every three years (the next meeting is in December 1982) to distribute largesse to those who have contributed to the council's coffers by work "outside normal duties". (In $1979, £ 130,000$ was distributed to 30 inventors in amounts ranging from $£ 40$ to some thousands of pounds.) The catch is that many commercially valuable
Department are also worried, since a strict interpretation of the regulations could prevent them from communicating research data, even if unclassified, to overseas affiliates.

The Defense Department, well aware of such objections and keen to avoid fresh campus confrontations such as those during the anti-war demonstrations of the 1960 s, hopes that its new guidelines will convince universities of its concern for the freedom of research. Its proposals have been circulated through the Association of American Universities, a group of top US research universities, and will be discussed at a meeting of university and government officials in Washington next week.

Faced with other financial problems, universities are keen not to rock the boat by rejecting the new requirements as unreasonable. But many are wary of what they are letting themselves in for - hoping that it is not the thin end of an increasingly sticky wedge.

David Dickson

inventions - like monoclonal antiinterferon - fall within normal duties, and so in principle outside the inventors' scheme. Nevertheless, the council says it will interpret the phrase liberally in future.

In the end, the central issue is not how the loot will be divided but whether there will be any loot at all. The council hopes that the fledgling and hungry Celltech will be more assiduous than its traditional partner, the National Research Development Corporation, in exploiting inventions. Proposals are already in hand with a number of potential customers interested in the purification and radioimmunoassay of interferon using the antibody. However, Hoffmann la Roche is also believed to have developed similar cell lines, so there may be commercial competition.

Then the question will be how good is the Celltech line? There is more than one kind of interferon, and Celltech's antibody is strictly an antibody to a single interferon, one from the group of interferons supplied by the Wellcome Laboratories (consisting of 8 to 16 proteins) which formed Burke and Secher's starting material. Nevertheless, says Burke, evidence is accumulating that their antibody will bind to similar sites in a number of related interferons, so its specificity may not be unduly narrow. The initial quantities of antibody will be produced in Cambridge. Ultimately production will move to Celltech's new laboratories in Slough. Celltech expects a modest market for interferon for clinical trials over the next few years, with the promise of a much larger market if interferon proves to have therapeutic value.

Robert Walgate 